\title{
UNLOCKING UNCULTIVATED FOOD FOR MOUNTAIN LIVELIHOOD: CASE FROM HINDU KUSH HIMALAYAS
}

\author{
Kamal Aryal', Rajan Kotru² and Karma Phuntsho ${ }^{3}$
}

\begin{abstract}
Throughout the Hindu Kush Himalayas, uncultivated plants provide a 'green social and cultural security' to millions of people supporting their livelihood. Review on evaluating the multifunctional role of uncultivated plants in perspective of livelihood support finds that plants add diversity to local food systems, reinforce local culture and contribute diversity to farming systems, and finally are important for household food and nutrition security, social security, income generation and health care. Further, this paper clarifies that local people maintain and conserve diversity for the sake of use. The wise conservation and use of uncultivated plants are essential elements for increasing food security, eliminating poverty, and maintaining the environment. However, the value and potential of uncultivated plants for food and nutrition security, household level health care, income generation opportunity are not yet realized. Fast changing climate and early projections on its impacts suggest that such programmes must increasingly consider the sustenance of ecosystem that promotes uncultivated plants as basis for the welfare of millions.
\end{abstract}

Key words: Uncultivated plants, food security, social security, livelihood support, multifunctional role, wild foods, Hindu Kush Himalaya

\section{INTRODUCTION}

All over the Hindu Kush Himalayan $(\mathrm{HKH})$ region, uncultivated plants provide a 'green social and cultural security' to millions of mountain people in the form of food, medicines, clothes and shelter (Sharma, 2008; Aryal et al., 2009). Uncultivated plants in this study are wild or uncultivated plant resources, which are harvested or collected, from natural and semi-natural environments, for the purpose of human use. The dietary use both as a food and nutrition of uncultivated plant resources is common among indigenous people in these areas (Bhattarai et al., 2009; Sundriyal and Sundriyal, 2001). Furthermore, wild relatives of crop varieties are also rich in this region. The important contribution that these resources can make to poverty reduction through enhancing household food security and incomes have been recognized in recent days (Adnan et al., 2012; Aryal, 2010; Aryal et al., 2009; Thapa, 2009). The significance of these resources further add value when Convention on Biological Diversity specifically mentioned wild species such as crop relatives and those of medicinal and agricultural value in

\footnotetext{
1 NRM analyst, International Centre for Integrated Mountain Development (ICIMOD), Tel + 977-15003222, karyal@icimod.org

${ }^{2}$ Regional Programme Manager, ICIMOD, rkotru@icimod.org

${ }^{3}$ Senior NRM specialist, ICIMOD, kphuntsho@icimod.org
} 
the indicative list of categories of the components of biological diversity to be identified and monitored (CBD 1994). The $3^{\text {rd }}$ Conference of Parties (COP) of Convention of Biological Diversity (CBD) mentions agenda item no. 9 under section 7 about the wild sources of foods importance to food and agriculture through improved management of Plant Genetic Resources for Food and Agriculture (PRGFA) in protected areas and elsewhere.

Shifting cultivation is a dominant land use across the eastern Himalayas starting from Nepal, through Bhutan, to the Chittagong Hill Tracts and the Northeast India. It is mostly the indigenous communities who depends on shifting cultivation and are dependent heavily on wild and uncultivated foods for their daily food. The contribution of uncultivated plants to livelihood support depends largely on individual circumstances (Piya et al., 2011; Aryal et al., 2009). Many thousands of "wild" species of plants provide important sources of protein, fats, vitamins and minerals. This is especially true for both the poorest and the richest socioeconomic groups of the people (ICIMOD, 2010; Aryal, 2010; Thapa, 2009; Akhtar, 2001)

Uncultivated foods are one of the major sources of the food supply for the people in the region in general and shifting cultivators in particular. Generally, these food crops are neglected in country programmes and policies (Aryal and Kerkhoff, 2008). So far, no concrete effort has been made to document and develop an inventory of these important plant species. There are very few studies done so far in the region though these resources contribute a significant role in livelihood support of the people. The main objective of this paper is compiling and evaluating the multifunctional role of uncultivated plants in the livelihood support of the people in the HKH region. To explore this we focussed mainly on two questions:

How do uncultivated foods fit into people's livelihood system?

How important these foods are for their social security?

\section{ANALYTICAL FRAMEWORK}

The whole review is based on the framework presented in the Figure 1 and the findings were analysed by using this framework. Uncultivated plants in this review represent all plant resources, which are harvested or collected for the purpose of human use from natural and semi-natural environments. The uncultivated plant species collected from the forest and nearby common property areas as well as from the agriculture field are crucial for the people of the region as it is their tradition to use such resources, which strongly contribute to their subsistence. Additionally, the cultural identity of the indigenous people is historically linked with the use of uncultivated plants to cover an ample range of needs such as food, vegetable, medicine, firewood, construction, handicrafts, and other various cultural and religious purposes (Aryal et al., 2009; Manandhar, 2002). Uncultivated plants have been used by the mountain people in $\mathrm{HKH}$ region since generations in the various forms to support their livelihood. This paper discusses the 
multifunctional role of uncultivated plants and their contribution in the wellbeing of the people living in the region.

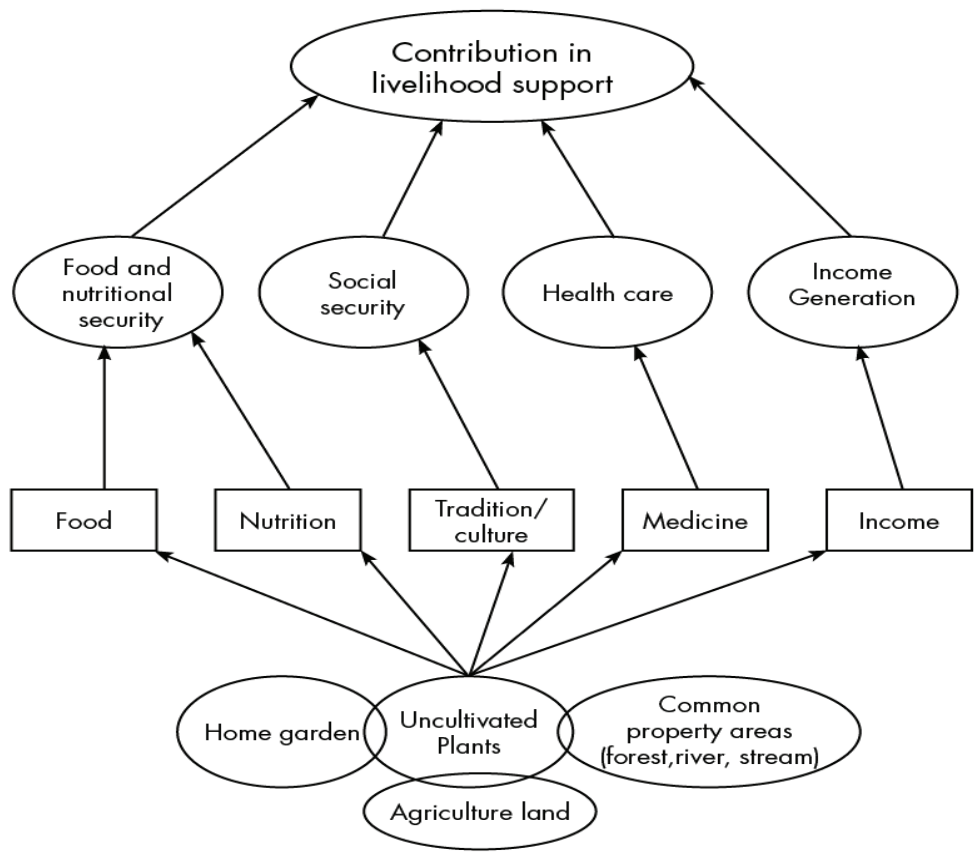

Figure 1. A framework of Multifunctional role of uncultivated plants (Adopted and modified from Ogle et al., 2001)

\section{METHODOLOGY}

Research methodology has been based on secondary as well as primary data. In the first stage, extensive desk review of published literatures on wild and uncultivated plants and their contribution in human well being around the globe were collected for the review. These literatures broadly analysed the use of uncultivated plants into four categories namely food and nutritional security, social and cultural security, income generation and household level health care. The articles collected were sorted out in the second stage according to the focus on $\mathrm{HKH}$ region. A total of 37 published articles from the $\mathrm{HKH}$ region which are most relevant and recent ones were identified for the detailed analysis. We set selection criteria for choosing the articles based on the four broad parameters (Food and Nutritional Security, Social Security, Income Generation and Health Care) that were used in global level. In addition, we collected some primary data through organizing Focus Group Discussion (FGD) in three pilot sites namely Chittagong Hill tracts of Bangladesh, Mongar district of Bhutan and Dhading district of Nepal. Overall, six FGD (two in each country) were conducted to gather first hand information on the use and status of the uncultivated plants in their community and to test above selection criteria. During the discussion, FGD was done with farmers who did the priority ranking for the reason of using these 
resources and majority of them ranked food security as the first, followed by cultural and social security, income generation options and household level health care. Besides, direct observations of the plants and consultations with experts were also done to validate the information.

\section{ANALYSIS AND DISCUSSIONS}

\section{FOOD AND NUTRITIONAL SECURITY}

Mountain people are dependent on the uncultivated foods for their daily food requirement (ICIMOD, 2010). Uncultivated plants provide an important source of food and supplement a variety of nutrients. A number of studies documented a wide range of uncultivated/wild plants and their uses. For example, Aryal (2010) has recorded 112 uncultivated plant species from Dhading and Kaski districts of Nepal, and Thapa (2009) has recorded 62 edible wild plants from Bhutan. Similarly, Tiwari (2003) has listed the use of over 380 Non-Timber Forest Products (NTFPs) collected from the shifting cultivation areas of the War Khasi region of Meghalaya, and Sundriyal et al. (2004) has recorded about 190 wild edible plants from Sikkim, India.

The contribution made to the food and nutrition supply to the individual households by these plants varies enormously from country to country. In the Chittagong Hill Tracts of Bangladesh, wild plants play a key role on household level food security during the times of drought and famine (Talukdar, 2012). Uncultivated foods in many rural parts of Bangladesh in general are the leafy greens and tubers collected from agricultural fields, shifting cultivation plots and fallow field, water bodies and forested areas constitute nearly $40 \%$ of the diet of the landless rural poor (SANFEC, 2005). These foods have been usedby the rural households to meet their daily food requirement (Talukdar, 2012; Akhtar, 2001).

In India, uncultivated food plants played an important role in the household food security of the Indigenous people living close to the forest (Tiwari et al., 2010; Misra et al., 2008; Reddy et al., 2007; Chhettri et al., 2005; DDS, 2002). Sinha and Lakra (2005) reported that $80 \%$ of the forest dwellers in West Bengal, Himachal Pradesh, Madhya Pradesh and Bihar and Orrisa depend on forest resources specially the wild food plants for about $25-50 \%$ of their total food supplies. Similar study carried out by Sundriyal and Sundriyal (2001) in Sikkim, India has reported that the uncultivated edible plants play a major role in meeting the dietary requirements of the tribal people and has also mentioned that these resources are more nutritious than cultivated food crops.

In Bhutan, number of traditional uncultivated vegetable plants are collected and consumed. These resources normally contribute greatly to the daily vegetable requirement of the household as well as contribute on nutritional well-being of rural people by providing the essential nutrients required for body growth and development and for prevention of diseases associated with nutritional deficiencies (Dorji, 2012). A case study on the contribution of wild yam (Dioscorea spp.) carried out in the Monpa community in central Bhutan and Martshalla village 
eastern Bhutan reported that the communities are indigenoususers of wild yams and live and rely on it as supplementary food for 4-5 months, from May-June to September-October, depending on availability. On average, one family consumes about $2 \mathrm{~kg}$ of tubers in a meal (Dorji, 2012).

In Nepal, there are number of studies which documented the uncultivated and wild plants and their associated use values for survival of the local people (Piya et al., 2011; Aryal et al., 2009; Bhattrai et al., 2009; Rijal, 2008b; Gurung, 2006; Shrestha and Dhillion, 2006; Pant et al., 2005). These resources form an important source of food and nutrition to the thousands of household living in the rural areas. Shrestha (2001) reported that uncultivated plant resources were one of the major sources of the food supply for many rural households. He estimated that it contributed about 20-30 percent of the food needs of a household in rural communities. Hundreds of wild plants have been used by the indigenous people in different parts of Nepal. For instance, a study carried out by Pant et al. (2005) has documented 83 species of wild edible plants which are used by the indigenous communities in Darchula districts of Nepal. These plant resources play an important role both in daily food requirement and dietary needs of the people.

A case study by Aryal et al. (2009) published in Ethnobotany, Research and Application Journal has been chosen to demonstrate the uncultivated plants and their contribution in the food security of the chepang people from the middle hills mountain district of Nepal.

The study documented 85 uncultivated plant species from 48 families; including $72 \%$ species with multiple functions as food, vegetables, and medicines. These resources contributed significantly to the household food security. The average contribution was 2.6 months a year with $58 \%$ of the households using foods from uncultivated source more than 3.5 months. Dioscorea bulbifera locally known as Gittha is the major uncultivated food source of the study area. All the respondents mentioned that this is a major crop traditionally been used for food purpose. This species significantly contribute in the food requirements of the family. Collection of this species has shown that people used to harvest upto 50 Kilograms per harvest. Mr. Ram Saran Chepang (40) has reported that he has collected 200 Kilogram of the roots (Bulb) of this plant from his 4 harvest. Hence, the uncultivated foods contributed significantly to food requirement of the Chepang people. Analysis on the use of species like Dioscorea bulbifera, Dioscorea deltoidea, Diploknema butyraceae andUrtica dioica shows that these species became the important part of Chepang culture.The availability of these species has declined over time. However, people have started in-situ conservation and domestication of several important species, Dioscorea bulbifera and Diploknema butyraceae. However, these resources are neglected in research and development activities.

In these circumstances, these resources play significant role in daily food requirement of the thousands of people living in HKH region, particularly in parts of rural village in Nepal, Bhutan, India and Chittagong Hill tracts of Bangladesh where shifting cultivation is the major agriculture farming practice; the 
consumption of wild-food plants seems to be one of the important local survival strategies of these people (Dorji, 2012; Talukdar, 2012; Aryal et al., 2009; Thapa, 2009). The contribution of uncultivated food is not merely a matter of satisfying hunger or overcoming stress conditions, it is also an essential part of the diet that must be ensured.

\section{HOUSEHOLD LEVEL HEALTH CARE}

A number of uncultivated plants having medicinal values have been used by the people in the region. Nontimber forest products in general and medicinal plants in particular are principle source of household health care of many rural households of the region (Adnan et al., 2012; Rijal, 2011; Shinwari, 2010; Thapa, 2009; Manandhar, 2002). Local people living in these areas since generations have been using these plant species through their indigenous knowledge to cure various diseases. They know the preparation of raw drugs from herbs through personal experience and ancestral prescription. These drugs were regularly used and have proved to be effective, cheap and beneficial with almost no side effects as compared to the allopathic drugs that are beyond the reach of poor locals (Adnan et al., 2012; Rijal, 2011; Aryal et al., 2009). Moreover, use of herbs by traditional health practitioners is due to their belief in such practices and religious connections about such practices (Rijal, 2011).

A number of studies have recorded large number of NTFPs. Many of these plants are using for the human health care for example, the leaves of Nasturium offiicinale and Hemerocallis sp. are believed to improve general condition of the blood; leaves of Mentha species and inflorescence of Girardiana palmate are believed to reduce blood pressure; and leaves of Urtica diocia are believed to cure tuberculosis (Thapa, 2009). The rapid expansion of the commercial use of these medicinal plants diversifies the income generation opportunity for mountain people. However, controlling illegal harvesting and over exploitation of these resources is the urgent need for their sustainable management.

\section{OPPORTUNITIES FOR INCOME GENERATION}

Besides their uses in household level food and health care, uncultivated medicinal plants have become products of major economic importance in recent years. Income derived from the collection and sale of uncultivated resources is particularly important for the rural poor as a source of cash for the purchase of other goods (Aryal and Kerkhoff, 2008; Piya et al., 2011; Reddy et al., 2007, Jena, 2003). Many uncultivated plant resources have significant economic value by preventing the need for cash expenditure, and income derived from the collection and sale of these resources. A study by Shinwari (2010) has mentioned that medicinal plants are a vital source of income for the local people of Himalayan moist temperate region of Pakistan and a number of plant species are traded for its medicinal value. The study by Jena (2003) reported that the local people in Similipal of Orrisa, India depend upon NTFP to supplement their income. In Rajabasa village of Similipal hills of Orrisa, India where local people collect about 24 NTFP items for sale in the market and they are gaining Rs 33,000 per annum. 
Aryal et al. (2013) reported that Chepang medicinal plant cooperative have been involved in marketing of some uncultivated plants in recent years. The cooperative has been supplying NTFPs namely Terminalia chebula, Terminalia bellirica, Phyllanthus emblica, Diploknema butyracea, Tinospora sinensis (dry vine @NRs 15 per $\mathrm{Kg}$ ), Asparagus racemosus (@NRs 300 per $\mathrm{kg}$ ) to some private companies namely Life Care (a company producing medicines), Gorkha Ayurved (Company producing homeopathic medicine), and Alternative Herbal Company. On average, farmers are earning NRs 7500/annum (about 100 US\$) from selling their medicinal plant products. Linking local products to the market through the cooperative has contributed to support the livelihood of Chepang community.

The selling of uncultivated fresh vegetables, fruits and NTFP's is not new in this region however the amount and the cash obtained from these resources is very low (Aryal et al., 2010; Thapa, 2009). Value addition and linking with market of some potential uncultivatedplants will diversify the income generation opportunity.

\section{RECOGNITION AND SOCIAL SECURITY}

Uncultivated food and their products are important elements in defining local or regional identity. In Bangladesh, uncultivated food is an important component of the region and culture. Therefore, the loss of uncultivated foods means loss of culture and religion and more (Akhtar, 2001). This cultural significance is often given tangible benefits as well. Most species and areas that are worshipped or protected for religious reasons by shifting cultivators can be found to have an important tangible value for livelihoods or ecological services. In Nepal, butter tree locally known as Chiuri (Diplokenma butyraceae) trees is one of the important tree species that are used as a gift (dowry) during the marriage of a girl from the parents thinking that it will help her during the food scarce period (Aryal et al., 2010). There is a tradition that you should eat at least a piece of Dioscorea or other tuber crops on the particular day i.e Maghe Sakranti (a popular winter festival celebrated on January 15 annually). During this festival, large number of uncultivated roots and tubers are brought for sale in fair of root crops. Similar example is the celebration of "Shoonyam panduga", a festival celebrated in India during December, when most of the crops are in harvesting stage. During this festival, the farming community worships mother earth by walking around a field, singing special songs related to the festival and offering food specially made out of more than twenty uncultivated greens, available during that time. A major reason for this celebration of diversity is the fact that uncultivated foods traditionally have been the source of food for the poor (Yesudas, 2004).People's high dependency on these resources is due to continuation of their traditional customs and culture that they find very comfortable to use it.

\section{CONSERVATION AND MANAGEMENT INITIATIVES AND ISSUES}

The true status of uncultivatedplants and there interrelationship with other species in the HKH region are yet not studied systematically. Available information is inadequate and is concentrated mostly on the specific species. Furthermore, 
uncultivated foods have received little attention in the scientific literature and food and nutrition programs of the government in the region.

The status and trend shows that we are losing our uncultivated plants day by day. However, in recent years, researchers and scientist are interested in the conservation of wild relatives of cultivated plants. Wild relatives are often used as sources of desirable genes in research related to the genetic improvement of crops. Therefore, the wise conservation and use of crop wild relatives are essential elements for increasing food security, eliminating poverty, and maintaining the environment (IPGRI, 2005).

People in the eastern Himalayas are quite knowledgeable about the use and conservation of thesehigh value indigenous species. Women are the principle collectors and users of the uncultivated foods. Ensuring daily food in the household is women's primary responsibilities in the region (Dorji et al., 2012; Talukdar, 2012; Aryal et al., 2010). Therefore, women want to manage these plant species for sustainable and future use. There are several examples that people brought wild species under their home garden for cultivation. When people see the benefits from the species, they conserve it. However, very limited systematic efforts have been made for the conservation and utilization of these plants (Adnan et al., 2012; Rijal, 2011; Thapa, 2009; SANFEC, 2005 and Shrestha, 2001). Without systematic documentation and database system there is a high chance of erosion of such important species and knowledge associated with its conservation. So there is a tremendous potentiality in this field for the sustainable utilization and management of the vast wild resources.

\section{CONCLUSIONS}

The HKH region consist of vast diversity of uncultivated plants having multiple use value needs to be conserved and managed for the livelihood support of the millions of people living in the region as well as equally important for the ecological restoration.

This review highlights that uncultivated plants provide substantial food and nutritional, social and cultural security as well as support on household level health care and economic benefits to the mountain people of eastern Himalayas. The analysis on its use by diverse users as food shows that uncultivated plant species have the potential to become valuable staple foods and important alternatives to the usual food crops cultivated by farmers. This is very significant as climate change impact are projected to cause serious threats to ecosystems and therefore to food security provided by the uncultivated plants from natural systems. The option to improve food production through unlocking the potential of uncultivated food plants might be a sustainable, cheap and local alternative for decreasing the food shortage problem. However, thefocus on the contribution of agriculture to total foodsecurity has resulted in the routine undervaluation ofuncultivated species. Policies on climate, conservation, food-security and agriculture need to be also integrated to recognize and preserve the importance of wild and uncultivated foods. Value addition through storage and 
commercialization of some important species probably widen the livelihood base of the mountain people and thus draw attention of planners and policy makers. Further more the traditional treatment of the question of food and food security is inadequate unless the contribution of uncultivated food is explored in detail and understood. This include both the ethno-botanical knowledge of people on uncultivated plants as well as their dynamic interaction with cultivated food and the various social, economic and cultural dimensions of the local food system.

Various studies maintain that local people only conserve the uncultivated and wild plant species when they see the long term benefits from their use. Furthermore, women because of their knowledge and experiences in harvesting and preparation of food recipe have greater practical knowledge on management of these species. Hence, maximum efforts should be given to documentation and integration of local knowledge on conservation and utilization of wild and uncultivated plants by establishing close linkage with the local people and their food production practices.

\section{ACKNOWLEDGEMENT}

We are very much thankful to the authors of the various publications. We would like to thank all the people of Bangladesh, Bhutan and Nepal who patiently share their knowledge and experiences on the use of uncultivated plants. We would also like to acknowledge the support provided by Canada's International Development Research Centre (IDRC) and International Centre for Integrated Mountain Development (ICIMOD) during preparation of this paper.

\section{REFERENCES}

Adnan, M, S. Begum, A.L. Khan, A.M.Tareen and I.J. Lee, 2012. Medicinal plants and their uses in selected temperate zones of Pakistani Hindu-Kush Himalaya. Journal of Medicinal Plants Research, 6(24): 4113-4127.

Akhtar, F., 2001. Uncultivated food in the context of poor people's livelihood: A Nayakrishi Experience. In Johnston, M.M. (eds.). Proceedings of the regional workshop on Uncultivated Foods and Biodiversity, September 24 to 26, Kathmandu, Nepal, pp.8-17.

Aryal, K.P,K. Thapa, R.Kotru, and K.Phuntsho, 2013. Fallow Management in Transforming Shifting Cultivation System. In: Malcolm Cairns (ed.), Growing Forest of Voices. Earthscan UK (on press).

Aryal, K.P.,2010. Uncultivated Plants in Nepal: An assessment of their richness and role in the livelihoods and culture of two indigenous communities. LAP LAMBERT Academic Publishing GmbH and Co. KG and Licensors, Germany.

Aryal, K.P., E.E. Kerkhoff, N. Maskeyand R. Sherchan, 2010. Shifting Cultivation in Sacred Himalayan Landscape. A Case study from Kangchenjunga Conservation Area. (c) WWF Nepal, First Edition.

Aryal, K.P., A. Bergand B.M.Ogle, 2009. Uncultivated Plants and Livelihood Support: A Case Study from the Chepang People of Nepal. Ethnobotany Research and Applications, 7:409-422.

Aryal, K.P. and E.E. Kerkhoff., 2008. The right to practice shifting cultivation as a traditional occupation in Nepal: A case study to apply ILO Conventions Nos. 111 
(Employment and Occupation) and 169 (Indigenous and Tribal Peoples). Kathmandu, International Labour Office, 2008.

Bhattarai, S., R.P. Chaudhary and R.S.L. Taylor, 2009. Wild edible plants used by the people of Manang district, central Nepal. Ecology of Food and Nutrition, 48 (1): 1-20

CBD, 1994. Conference of the parties to the convention on biological diversity, Third meeting Buenos Aires, Argentina 4 to 15 November 1996 Item 8.1 of the provisional agenda

Chhetri, N., E. Sharma and S.D. Lama, 2005. Non Timber Forest Produces utilization, distribution and status in a trekking corridor of Sikkim, India. Lyonia, 8(1): 89-101.

DDS, 2002. Uncultivated food and poor, Published in India together http://www.indiatogether.org/agriculture/dds/uncultivated.htm accessed on 15 February 2013.

Dorji, Y., 2012. Women's roles in wild yam, conservation, management and use in Bhutan. In Khadka and Verma (eds.), Gender and Biodiversity Management in the Greater Himalayas, ICIMOD, pp 25-27.

Gurung, B., 2006. Chepang Mainstreaming Programme, a brief introduction. Voice of Chepang, a monthly newsletter (in Nepali), Kathmandu Nepal, Nepal Chepang Association, pp 4-10.

ICIMOD, 2010. Mountain Biodiversity of the Hindu Kush-Himalayas. International Year of Biodiversity 2010.

IPGRI, 2005. Wild relatives, in situ conservation of Agricultural biodiversity. Conservation of Crop Wild Relatives in Natural Ecosystems

Jena, M.K., 2003. Economical and Biological Potential of Non-Timber Forest Products (NTFP) in the Similipal Hills of Orissa. In Seeland and Schmithusen (eds.), Indigenous Knowledge, Forest Management and Forest Policy in South Asia. Man and Forest Series 5, pp 81-103.

Manandhar, N.P., 2002. Plants and people of Nepal/Narayan P. Manandhar with the assistance of Sanjaya Manandhar. Timber press, Portland, Oregon, USA., PP 15-41.

Misra, S., R.K. Maikhuri, C.P. Kala, K.S. Rao and K.G. Saxena, 2008. Wild leafy vegetables: A study of their subsitence dietetic support to the inhabitants of Nanda Devi Biosphere Reserve, India. Journal of Ethnobiology and Ethnomedicine, 4:15, http://www.ethnobiomed.com/content/4/1/15 accessed on 10 March 2013.

Ogle, B. M., Dao Anh,Ha Thi, M. Generose and H. Leif, 2001.Micronutrient composition and nutritional importance of gathered vegetables in Vietnam. International Journal of Food Sciences and Nutrition, 52: 485-499.

Pant, S.R., N.R. Dhami and I.R. Pant, 2005. Wild edible plants of Lekam area, Darchula, Far-western Nepal. Sceintific wolrd, 3 (3): 73-77.

Piya, L., K.L. Maharjan and N.P.Joshi, 2011. Forest and Food Security of Indigenous People: A case of Chepangs in Nepal. Journal of International Development and Cooperation 17(1): 113-135.

Reddy, K.N., C. Pattanaik, C.S. Reddy and V.S. Raju, 2007. Traditional knowledge on wild food plants in Andhra Pradesh. Indian Journal of Traditional Knowledge 6 (1): 223-229.

Rijal, A., 2008b. A quantitative assessment of indigenous plant uses among two Chepang communities in Central mid-hills of Nepal. Ethnobotany Research and Application, 6: 395-404.

Rijal, A. 2011. Surviving Knowledge: Ethnobotany of Chepang Community from mid hills of Nepal. Ethnobotany Research and Application 9: 181-215

SANFEC, 2005. Forgotten Food. Food that money can't buy (This article is a reproduced from the South Asia Network on Food, Ecology and Culture (SANFEC) Policy Brief No. 1: 
http://www.grain.org/seedling_files/seed-05-01-5.pdf accessed on 12 February 2013.

Sharma, E., 2008. Developing a transboundary biodiversity conservation landscape and conservation corridors in the Kangchenjunga complex. In Chettri et al. (eds.). Biodiversity Conservation in the Kangchenjunga Landscape, ICIMOD. Pp 3-10

Shrestha, S.R., 2001. The state of Uncultivated Foods in Nepal Biodiversity and Uncultivated food plants. In Johnston, M.M. (eds.). Proceedings of the regional workshop on Uncultivated Foods and Biodiversity, September 24 to 26, Kathmandu, Nepal. Pp 33-39.

Shrestha, PM and S.S. Dhillion, 2006. Diversity and traditional knowledge concerning wild food species in a locally managed forest in Nepal. Journal on Agroforestry system, 66 (1): 55-63.

Sinha, R and V. Lakra, 2005. Wild tribal food plants of Orissa. Indian Journal of Traditional Knowledge. 4(3) 246-252

Shinwari, Z.K., 2010. Medicinal plants research in Pakistan. Journal of Medicinal Plant Research 4: 161-176.

Sundriyal, M and RC. Sundriyal, 2001. Wild edible plants of the Sikkim Himalaya: Nutritive values of selected species. Economic Botany, 55:377-390.

Sundriyal, M., R.C. Sundriyal and E. Sharma,2004. Dietary use of wild plant resources in the Sikkim Himalaya, India. Economic Botany 58(4): 626-638

Talukdar, T., 2012. Women's as key managers of biodiversity in Shifting Cultivation in Bangladesh. In Khadka and Verma (eds.), Gender and Biodiversity Management in the Greater Himalayas, ICIMOD, pp 21-24.

Thapa, L., 2009. The Research Project on Edible Wild Plants of Bhutan and Their Associated Traditional Knowledge. Journal of the Faculty of Agriculture SHINSHU UNIVERSITY Vol.45 No.1: Pp 43-47.

Tiwari, J.K.,R. Ballabha and P. Tiwari, 2010. Some promising wild edible plants of Srinagar and its adjacent area in Alaknada valley of Garhwal Himalaya, India. Journal of American Science 6 (4): 167-174.

Tiwari, B.K.,2003. Traditional Management of NTFP/MAPs in North East India: A Case Study of Bayleaf and Broom Grass. Paper presented at a Consultation Meeting on Improving Livelihoods of Mountain Communities through Sustainable Utilization of Non-Timber Forest Products at ICIMOD, 18-20 December 2003, Kathmandu, Nepal.

Yesudas, B.S., 2004. Conservation of uncultivated foods by local communities. LEISA India, vol.6, Issue 1- Valuing Crop Biodiversity. 